\title{
EFFECT OF STIFFENERS IN LATERAL STIFFNESS OF MASONRY INFILL REINFORCED CONCRETE (RC) FRAMES
}

\author{
Chandra Kiran Kawan
}

Departement of Civil Engineering, Khwopa College of Engineering, Libali-2, Bhaktapur, Nepal

\begin{abstract}
Infilled frames are reinforced concrete frames with masonry infill. The provision of masonry walls as infill increases the lateral stiffness of frame. Unreinforced masonry infill effects the strength and stiffness of frame but being ignored for a long teime. The main objective of this paper is to study the individual and combined effect of infill masonry wall, stiffeners and wooden frame in the lateral stiffness of infill reinforced concrete frame with central opening, with and without gap element consideration. From the analysis using SAP software, it is observed that with increase in openings, stiffness decreases but introducing stiffeners and wooden frame increases the lateral stiffness. Embedding the gap element as the boundary condition reduces the stiffness of the infilled frame. Numerical investigations are carried out by finite element modeling for analyzing the behavior of infilled frame. The single equivalent diagonal strut width was determined by obtaining the same lateral stiffness from finite element model, and also strut reduction factor for different conditions with central openings are proposed.
\end{abstract}

Keywords: Infilled frame, masonry infill, stiffener, gap elements, equivalent diagonal strut width

\section{Introduction}

Masonry infill increases the strength of frame but it is neglected due to lack of proper guideline for structural designers in building codes. Structural contribution of infill wall cannot be ignored in regions like Nepal which lies in high seismic region. In residential building $\mathrm{RC}$ frame structure is infilled by brick panels on four sides which resist the lateral earthquake loads. Experimentally, it has been shown that brick wall has high lateral stiffness (Pauley et al., 1992). In masonry infilled RC frame, lateral load transfer mechanism of the structure changes from predominant frame action to predominant truss action (Murty et al., 2000). Infill wall in RC frame has contribution to lateral load resisting capacity of frame structure increasing its lateral strength and stiffness.

\footnotetext{
*Corresponding author: Chandra Kiran Kawan Department of Civil Engineering, Khwopa College of Engineering, Libali-2, Bhaktapur, Nepal

Email: kawan.chandra1@gmail.com

(Received: 2015 June 02 Accepted: 2015 September 03)
}

But presence of opening (doors and windows) reduces the stiffness of infilled masonry so its size and position should be maintained properly. Codes (NBC 105:1994, IS1893:2002) do not consider the strength and stiffness of infilled frames with openings. In these codes, role of infill wall is considered in terms of fundamental time period. Hence, the behavior of infilled frames with openings in lateral seismic loading needs to be studied extensively which helps to develop a rational approach or guidelines for design. In the present study, a finite element (FE) analysis has been carried out on single-bay single-story infilled frame to examine the effect of different sized central openings on the initial lateral stiffness of infilled frame, considering different boundary conditions.

Usually RC bands/ stiffeners while used in the opening increase the stiffness of the infilled frame. The strength and stiffness reduction factor decreases when the strengthening elements are present around the opening, and the influence of the opening size diminishes when the opening is strengthened (Buch S. H. et al., 2012, Decanini L. D. et al., 2012). Presence of stiffeners in the infilled 
frame increases the lateral stiffness offered by the masonry and compensate the reduced stiffness due to opening, and lintel band has significant role than the stiffeners around the opening (Arjun P. et al., 2014). The addition of the wooden choh- kat (wooden typical windows) increases the initial lateral stiffness by $12-15 \%$ of central openings of area $40 \%$ compared to the initial lateral stiffness of same infill openings without choh-kat (Buch S. H. et al., 2012). Avoiding these stiffening members while designing may result in the boost of lateral strength of the buildings.

The equivalent frame model is based on the concept of equivalent frame, where members have the properties of the composite sections of the actual structure (Liauw 1972, Kodur et al. 1998). The equivalent diagonal strut model is the most simplified yet reasonably accurate macro-model which is usually done by modeling the infill panel as a single diagonal strut connected to the two compressive diagonal corners. There are several articles which have been made to compute the effective width of diagonal strut for infilled frames without opening (Holmes 1961, Smith and Carter, 1969, Mainstone 1971, Liauw and Kwan 1984, Paulay and Priestley 1992). The effective width of diagonal strut for infilled frame without opening may be reduced by a reduction factor to simulate the presence of openings of various aspect ratios in the infilled frame (Durrani A. J. et al. 1994, AlChaar 2002).

\section{Methodology}

To obtain the lateral stiffness of infilled frames with varying sizes of central opening, parametric study is performed which consist of two types of analysis method: FE method (Micro model) and SEDS (Single Equivalent Diagonal Strut) method (Macro model). FE model with full infill masonry wall was first calibrated using published results of experimental specimens available (Dorgi $\mathbf{J}$ et al., 2009). This verified model as shown in Fig 1 is also modified as per requirement. The width of Equivalent diagonal strut for the SEDS method is estimated so as to obtain the same lateral stiffness as estimated from FE method. In this study, single bay single storey RC infilled frame is analyzed, and lateral stiffness is determined. A bare frame, a fully infilled frame and frame using stiffeners (sill band, lentil band and wooden frame) with central openings $3 \%, 5 \%, 10 \%, 20 \%, 30 \%, 40 \%, 50 \%$ are taken for analysis, and initial lateral stiffness is obtained for each condition by the software SAP 2000 v17.0.0.

\section{Input parameters}

A single-bay single-storey masonry infilled reinforced concrete frame was modelled using the published experimental specimen (Dorgi $\mathbf{J}$ et al., 2009). Masonry infill with $3 m * 3 m$ size has been considered. In between frame and infill, gap element is provided which transfers the compressive force only. Beam size $500 \mathrm{~mm} * 420$ $\mathrm{mm}$ and column size $375 \mathrm{~mm} * 375 \mathrm{~mm}$, infill wall thickness $200 \mathrm{~mm}$ are modelled. Effective damping value of gap element is 0.05 . Masonry with compressive prism strength $4.75 \mathrm{MPa}$, and concrete with characteristic compressive strength $\left(f_{\mathrm{ck}}\right)$ of 25 MPa is defined. The Poisson's ratio of masonry and concrete is 0.15 and 0.2 respectively. Modulus of elasticity of masonry is $3562.5 \mathrm{MPa}$, using the empirical relation $\mathrm{E}=750 * \mathrm{f}_{\mathrm{m}}$ ( $\mathrm{f}_{\mathrm{m}}$ is compressive strength of 4.75 MPa of masonry) (Pauley, 1992), and concrete is $2400 \mathrm{MPa}$ and densities of masonry and concrete are $19.6 \mathrm{KN} / \mathrm{m}^{3}$ and $24 \mathrm{KN} / \mathrm{m}^{3}$ respectively. In addition, for wooden model, Sal wood with modulus of elasticity $\mathrm{E}=126700 \mathrm{KN} / \mathrm{m}^{2}$, Poisson ratio $=0.3$, weight per unit volume $=7.8944$ $\mathrm{KN} / \mathrm{m}^{3}$ is taken.

\section{Model development}

A single bay, single storey reinforced concrete frame with masonry infill was modeled for validation. The aspect ratio of the model is $3 \mathrm{~m}$ in height and length. In this model the interface between the frame and the infill is provided with the gap elements which have the capability to transfer only compressive load to and from the infill masonry. Approximately $30 \%$ decrease of the lateral stiffness was observed when horizontal gap of $1.5 \mathrm{~mm}$ between the upper beam and the infill wall was made in his experimental test on the steel frame (Mainstone, 1971). There are two columns, one at each side, and two beams each at the top and bottom. A fixed support condition is provided at the base of the two columns while beam column joints were rigidly connected. The structural members 
(beams and columns) were modeled as frame elements while the infill masonry was modeled with plane stress elements. The infill panels were meshed with finite elements of $150 \mathrm{~mm}$ square in size in order to avoid the infill behaving as a shear panel, to increase the accuracy of the result and to provide adequate convergence of results. The size of the finite elements used to model the beams and columns were $150 \mathrm{~mm}$ long. The above model was developed to match the model by previous research (Dorji J et al., 2009). The size of the column section was $375 \times 375 \mathrm{~mm}$ square and the beam section was $500 \mathrm{~mm}$ deep and $420 \mathrm{~mm}$ wide and the infill was $200 \mathrm{~mm}$ thick.
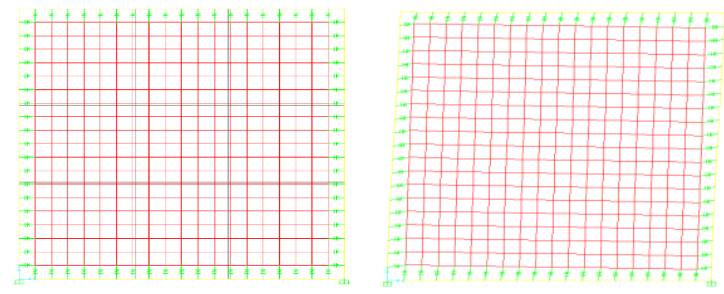

Fig 1 Full infill undeform and deform shape
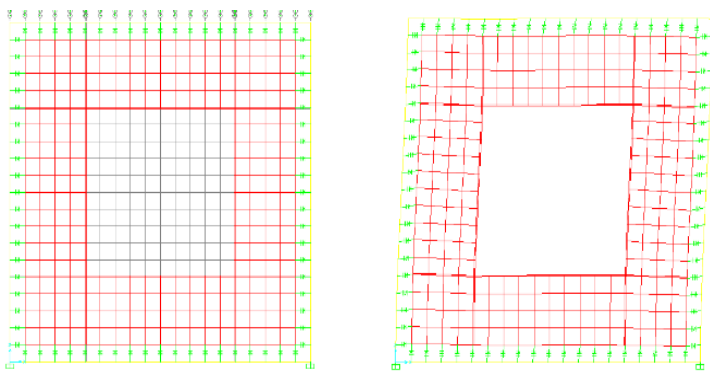

Fig 2 Infill with $30 \%$ opening undeform and deform shape

Stiffeners of size $75 \mathrm{~mm}, 100 \mathrm{~mm}, 150 \mathrm{~mm}$ width are modeled. The thickness of stiffener is kept 200 $\mathrm{mm}$ i.e. same as the thickness of infill wall. The stiffeners are modeled as frame member joining to points in the columns at sill and lintel level of the infill which act as the sill band and lintel band for the opening. Also, wooden window frame model is prepared in SAP 2000 as frame member with sectional area $75 \mathrm{~mm}$ by $75 \mathrm{~mm}$. The strut is connected to the diagonal nodes at the beamcolumn joints so that it can take only axial force. The thickness of strut is kept same as that of infill. Cracked flexural rigidity of components and modulus of elasticity of strut is kept same that of infill. The typical SAP models for different aspects are shown in Fig 1- 7.
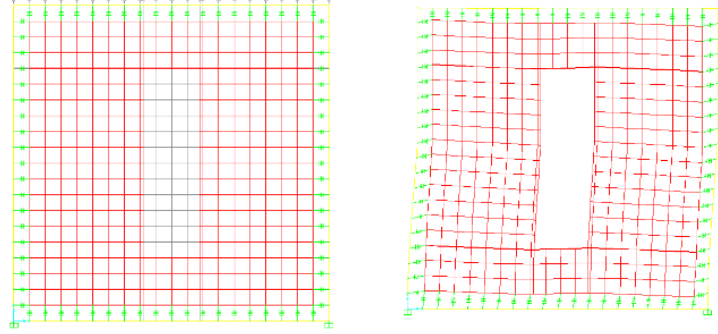

Fig 3 Infill with aspect ratio ho/h=0.67
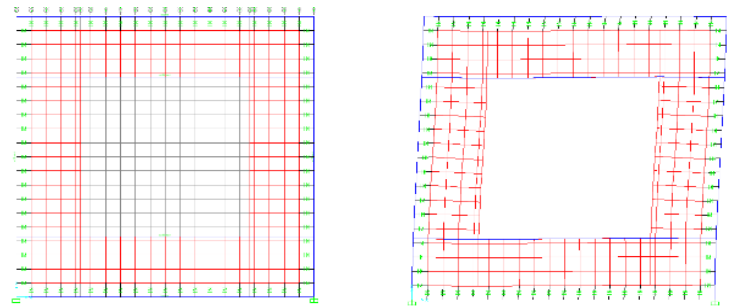

Fig 4 Infill with $40 \%$ opening with lintel and sill band without gap element undeform and deform shape
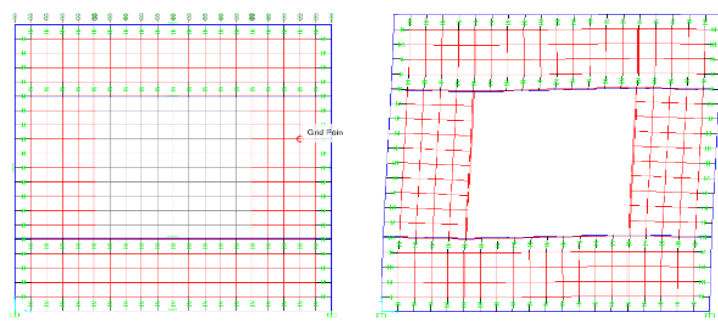

Fig 5 Infill with 30\% opening with lintel and sill band with one side gap element undeform and deform shape

\section{Effects of central opening on the stiffness of solid infill frame}

Openings for ventilation purpose (doors and windows) in masonry are inevitable, and such openings reduce the lateral stiffness of infilled frame. Infill with varying central opening to infill frame is examined, and found that opening size less than $3 \%$ behaves as full infilled frame and opening size greater than $50 \%$ behaves as bare frame (Fig 8).
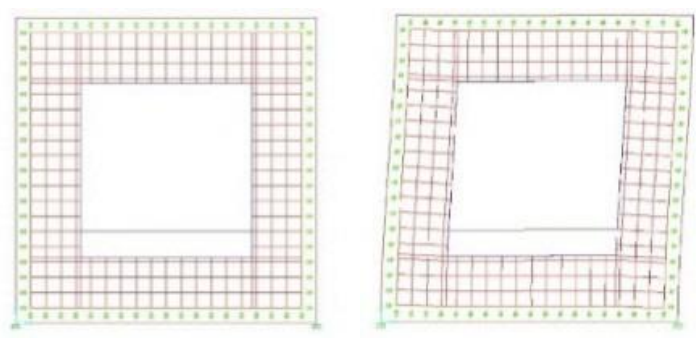

Fig 6 Infill with $40 \%$ opening wooden frame undeform and deform shape 

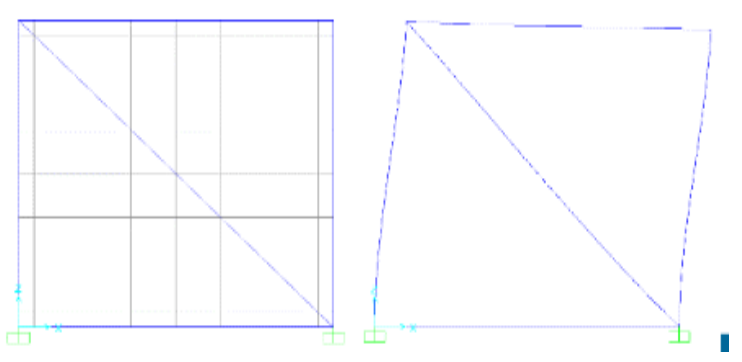

Fig 7 Single equivalent diagonal strut model undeform and deform shape

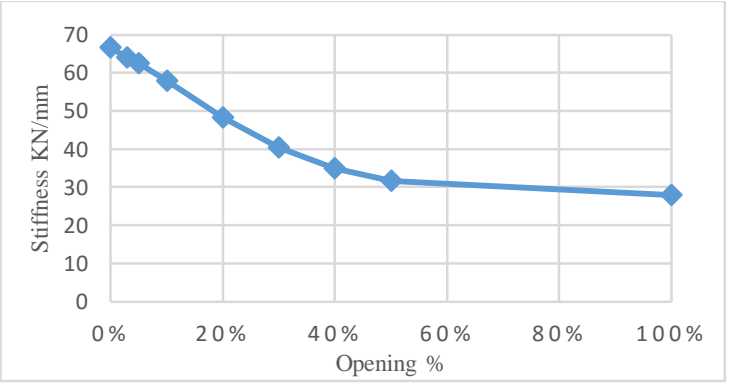

Fig 8 Stiffness Vs opening \%

\section{Effects of stiffeners on the lateral stiffness of infill frames with openings}

Reduction in lateral stiffness due to openings can be compensated by using stiffeners. Different sizes of stiffener (lintel band, sill band or both lintel and sill band) around opening are used. Stiffness of infilled frame is influenced by the stiffener adopted. Hence in the present study, effect of stiffener on the lateral stiffness of infill frame has been studied and comparative studies are reported. The thickness of stiffener varies from $75 \mathrm{~mm}, 100 \mathrm{~mm}$ and $150 \mathrm{~mm}$ keeping same width as infill.

From analytical result it can be proposed that lateral stiffness of frame structure increases with the use of stiffeners. Also increase in the size of stiffeners increase the lateral load resisting behavior of frame structure. From Fig 9, use of 75 mm lintel stiffener can increase the stiffness up to $17 \%$ for $20 \%$ opening and up to $10 \%$ for $40 \%$ opening size. Similarly $100 \mathrm{~mm}$ and $150 \mathrm{~mm}$ lintel stiffeners increase in stiffness is $22 \%$ and $27 \%$ for $20 \%$ opening and increase is $13 \%$ and $17 \%$ for $40 \%$ opening. From Fig 10, when gap element is used only at upper side of stiffeners there is only $2 \%$ and $3 \%$ increase in stiffness for $20 \%$ and $40 \%$ opening respectively for $75 \mathrm{~mm}$ lintel stiffener. Similarly, for $100 \mathrm{~mm}$ and $150 \mathrm{~mm}$ stiffener there is $7 \%$ and $14 \%$ increase in $20 \%$ opening and $6 \%$ and $9 \%$ increase in stiffness for $40 \%$ opening respectively.

\subsection{Stiffeners as lintel band with and without gap}

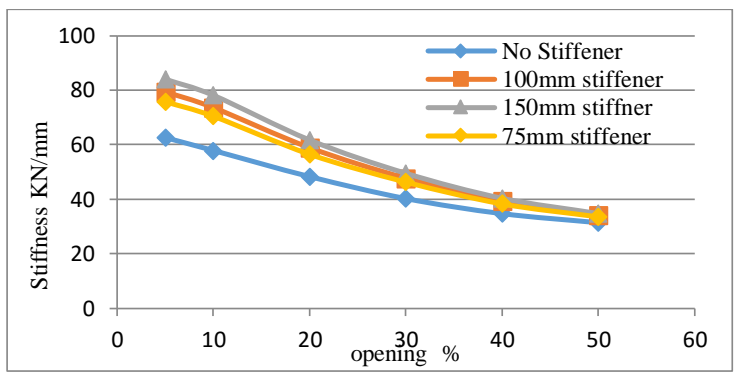

Fig 9 Comparison of Infilled Frame stiffened by varying thickness of Lintel band without gap element

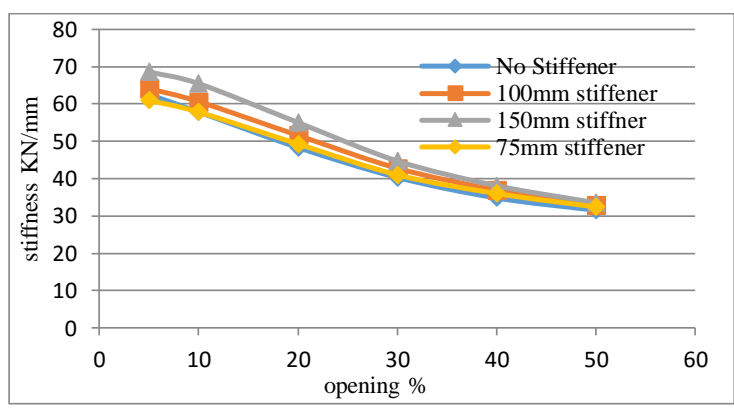

Fig 10 Comparison of Infilled Frame stiffened by varying thickness of Lintel Stiffener with one side gap

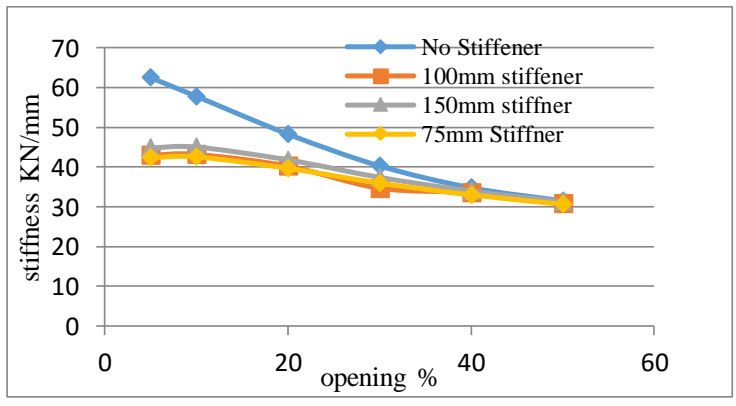

Fig 11 Comparison of Infilled Frame stiffened by varying thickness of Lintel Stiffener with both side gap

While gap element is used at both sides of stiffeners there is reduction in stiffness of frame structure i.e. reduction in stiffness due to gap element is greater than stiffness increase by stiffeners. Fig 11 clearly shows the effects of gap element. For opening size greater than $40 \%$ there is no significant increase in 
stiffness of frame structure with use of stiffeners, hence infill frame with opening greater than $40 \%$ can be treated as bare frame.

\subsection{Stiffeners as the lintel and sill bands with and without gap}

Use of both lintel and sill bands in the infill with openings are in practice in Nepal. From this study it is proposed that use of both lintel and sill bands of varying size increase the lateral stiffness significantly. From Fig 12 for $75 \mathrm{~mm}$ stiffener there is $33 \%$ and $17 \%$ increase in stiffness for opening size $20 \%$ and $40 \%$ respectively.

Similarly when stiffener size increase to $100 \mathrm{~mm}$ and $150 \mathrm{~mm}$, increase in stiffness rise up to $40 \%$ and $48 \%$ for $20 \%$ opening size and increase is up to $21 \%$ and $25 \%$ for opening size $40 \%$. But when gap element is used there is decrease in stiffness which is clearly shown in Fig 13 and Fig 14.

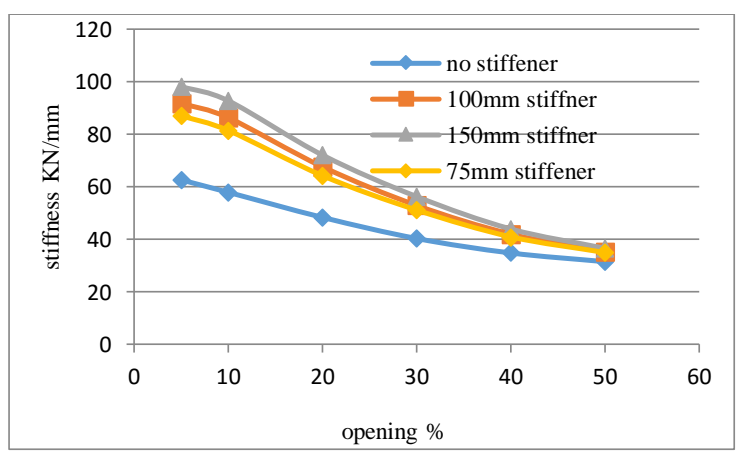

Fig 12 Comparison of infilled frame stiffened by varying thickness of lintel and sill stiffeners without gap element.

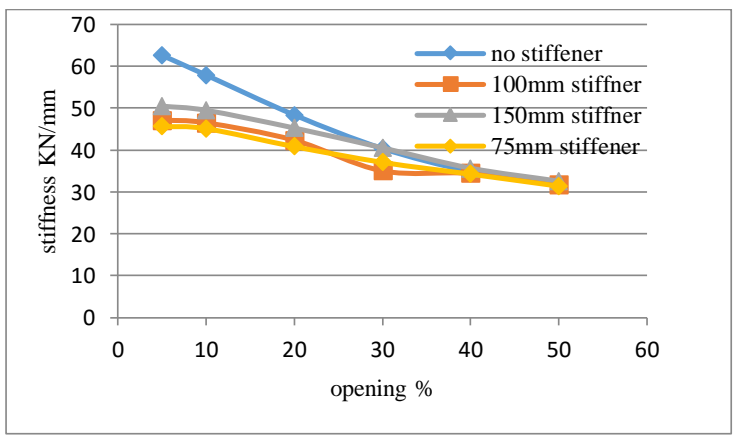

Fig 13 Comparison of infilled frame stiffened by varying thickness of lintel \& sill stiffener with one side gap

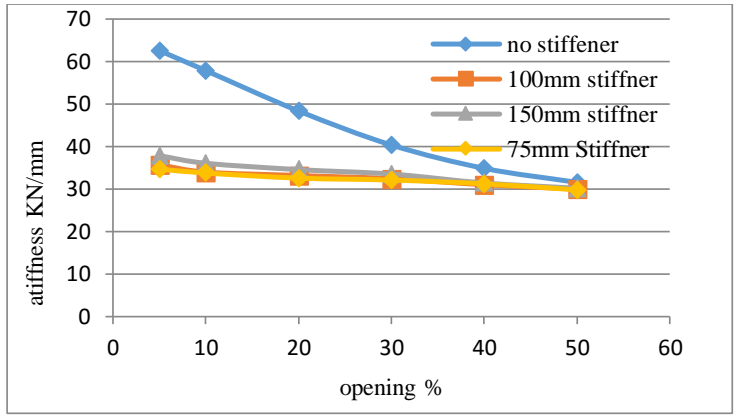

Fig 14 Comparison of infilled frame stiffened by varying thickness of lintel \& sill stiffener with both sides gap

\section{Effects of wooden frame with stiffener on the lateral stiffness of infill frames with openings}

Wooden frame of standard layout normally used in Nepal is embedded in the infilled frame in combination to lintel and sill band. This is the holistic model that represent the real infill frame. While in cooperating the gap element in the embedded frame, lateral stiffness increment is very negligible. So, its graphical illustrations are not mentioned here.

\subsection{Wooden frame with lintel band without gap}

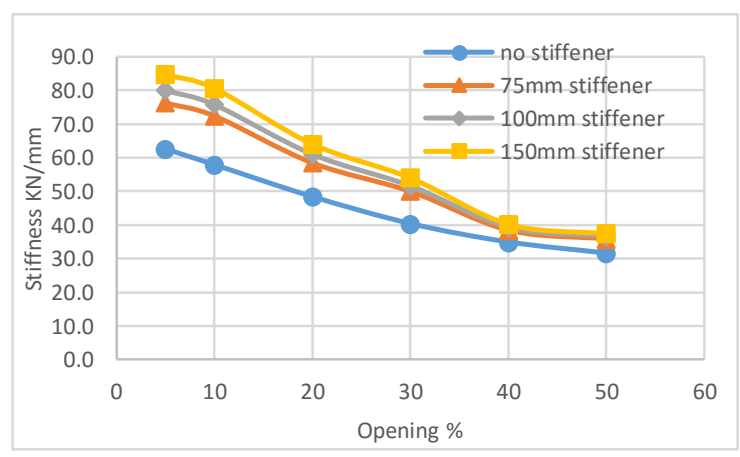

Fig 15 Infilled frame with wooden frame and lintel band

Lateral stiffness of infilled frame with wooden frame and lintel band increases as shown in Fig15 for different opening. Use of $75 \mathrm{~mm}$ lintel stiffener with wooden frame increase stiffness up to $21.05 \%$ for $20 \%$ opening and up to $12.55 \%$ for $40 \%$ opening. For $100 \mathrm{~mm}$ and $150 \mathrm{~mm}$ lintel stiffener with wooden frame, increase in lateral stiffness is $26.22 \%$ and $32.69 \%$ for $20 \%$ opening and $15.73 \%$ and $13.93 \%$ for $40 \%$ opening respectively.

From analysis, the lateral stiffness of infilled frame with wooden frame, lintel and sill band increase the lateral stiffness as shown in Fig 16. For 75 mm, 100 
$\mathrm{mm}$ and $150 \mathrm{~mm}$ lintel stiffener with wooden frame, increase in lateral stiffness is $37.08 \%$, $43.74 \%$ and $54.47 \%$ for $20 \%$ opening and $20.58 \%$, $24.02 \%$ and $25.87 \%$ for $40 \%$ opening respectively.

\subsection{Wooden frame with lintel and sill band without gap}

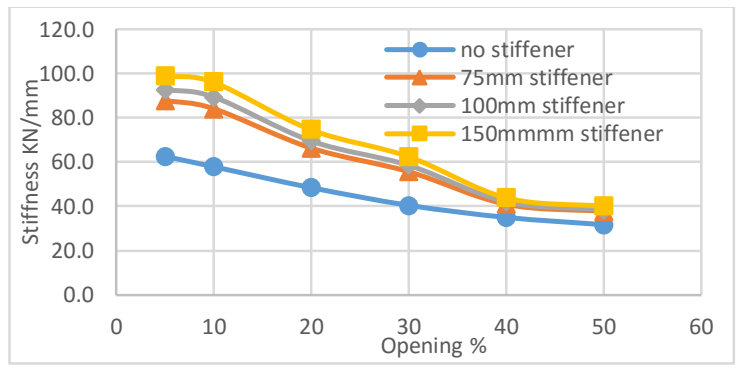

Fig 16 Infilled frame with wooden frame and lintel and sill band

\section{Single Equivalent Diagonal Strut (SEDS) width Analysis}

Initial lateral stiffness of infill frame of single storey single bay is also obtained by SEDS analysis. Infill is modelled as single equivalent diagonal strut, the strut is connected to the diagonal nodes at the beam-column joint so it can take only axial force. The thickness of strut is kept as that of infill.

From Fig 17, width of single equivalent diagonal strut can be obtained for different opening sizes. Each curve in graph indicates the different opening height ratio. This curve is valid for opening percentage in between $3 \%$ to $50 \%$. A sharp decrease of initial stiffness has been observed when opening is extended up to full height or full width. For example, opening width ratio of 0.5 and opening height ratio 0.5 , width of equivalent strut $=0.048 * \mathrm{~d}$ where ' $\mathrm{d}$ ' is diagonal length of infill panel. From Fig A, equivalent strut width for infill with different opening aspect ratio with various stiffener size which is used as lintel and sill band can be obtained. Equivalent strut width increases with the application of stiffener. Width of equivalent strut increases as the thickness of stiffener increases. For example, width of equivalent strut for $75 \mathrm{~mm}, 100 \mathrm{~mm}, 150 \mathrm{~mm}$ stiffener in lintel band for different aspect ratio are obtained as $0.070 \mathrm{~d}, 0.069 \mathrm{~d}, 0.12 \mathrm{~d}$ respectively (Fig 18.2 to Fig 20). And similarly width of equivalent strut for $75 \mathrm{~mm}, 100 \mathrm{~mm}, 150 \mathrm{~mm}$ stiffener in lintel and sill band for different aspect ratio are obtained as $0.075 \mathrm{~d}, 0.095 \mathrm{~d}$, and $0.98 \mathrm{~d}$ (Fig 21 to Fig 23). When wooden frame is introduced around the opening with stiffeners increase the stiffness. But when wooden frame is introduced in opening without stiffeners there is negligible increment in stiffness. Equivalent strut width for infill with wooden frame around the opening with different aspect ratio and various stiffener size which is used as lintel and sill band as shown in Fig B can be obtained. Width of equivalent strut increases when wooden frame is introduced. For example, width of equivalent strut for $75 \mathrm{~mm}, 100 \mathrm{~mm}, 150 \mathrm{~mm}$ stiffener in lintel band for different aspect ratios are obtained as $0.051 \mathrm{~d}, 0.075,0.06 \mathrm{~d}$ (Fig 24 to Fig 26). Similarly, width of equivalent strut for $75 \mathrm{~mm}, 100$ $\mathrm{mm}, 150 \mathrm{~mm}$ stiffener in lintel and sill band for different aspect ratios are obtained as $0.13 \mathrm{~d}, 0.18 \mathrm{~d}$, and 0.175 d(Fig 27 to Fig 29) when wooden frame is introduced around the opening.

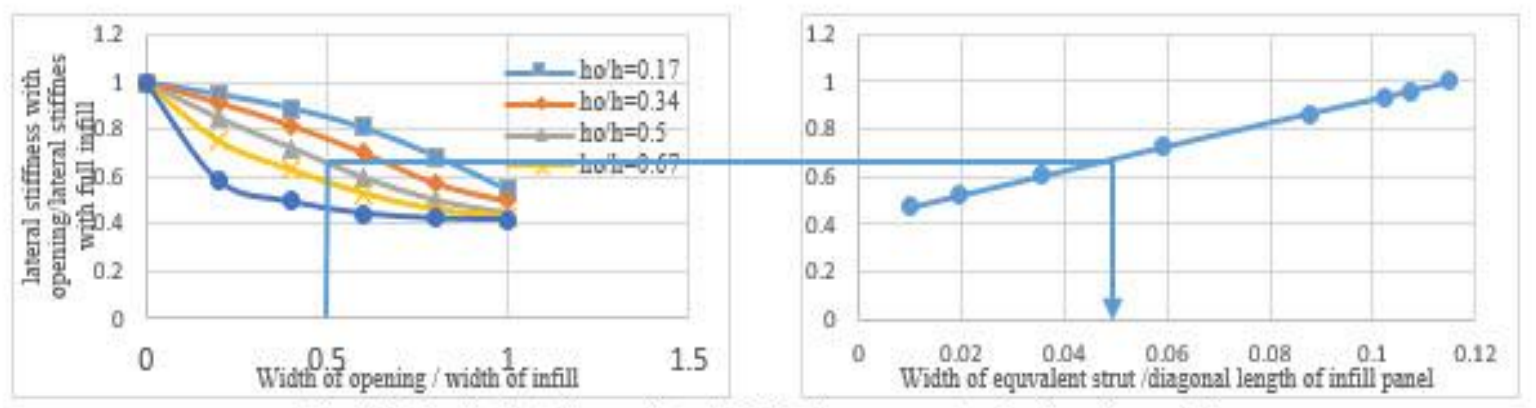

Fig. 17. Equivalent diagonal strut obtain from aspect ratio (opening only) 


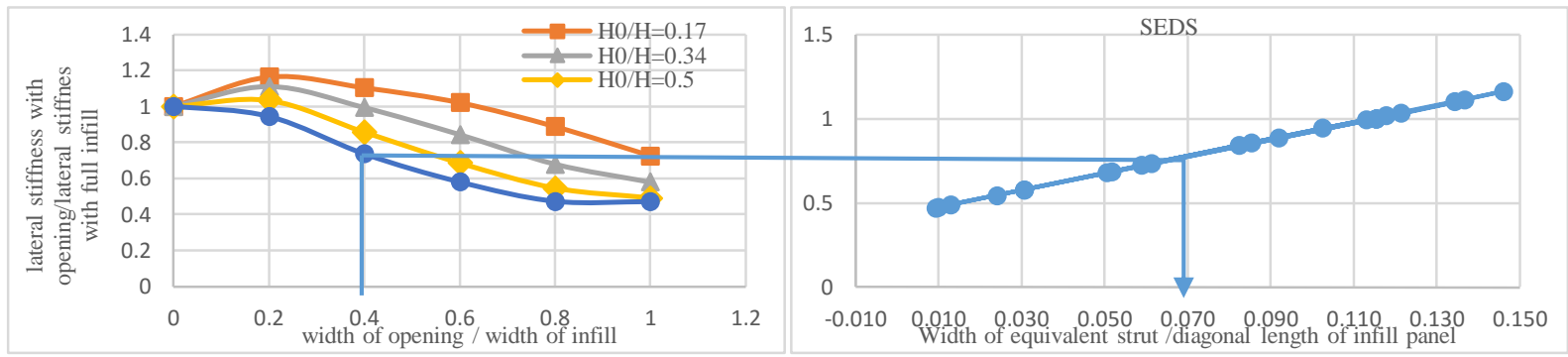

Fig 18 Single equivalent diagonal strut for lintel $75 \mathrm{~mm}$ stiffener

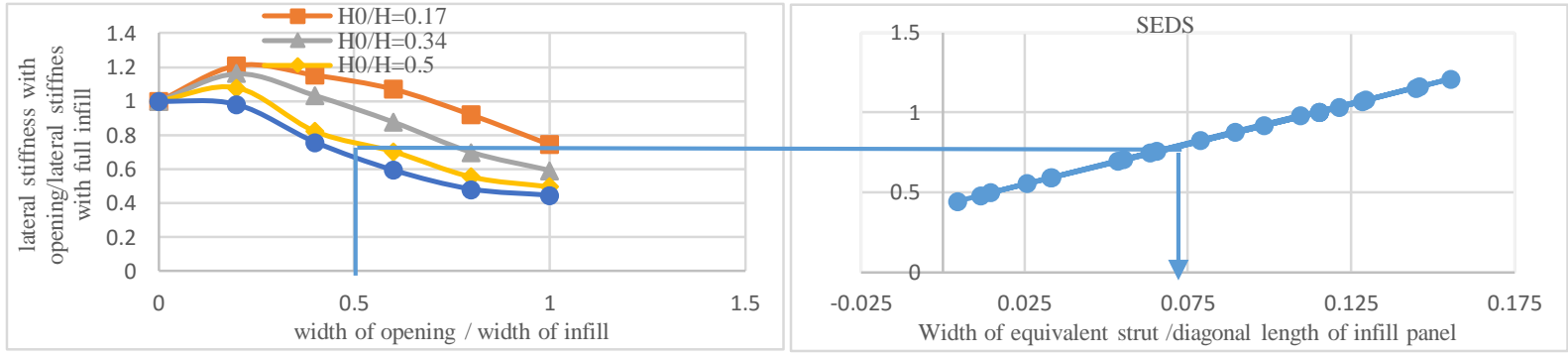

Fig 19 Single equivalent diagonal strut for lintel $100 \mathrm{~mm}$ stiffener

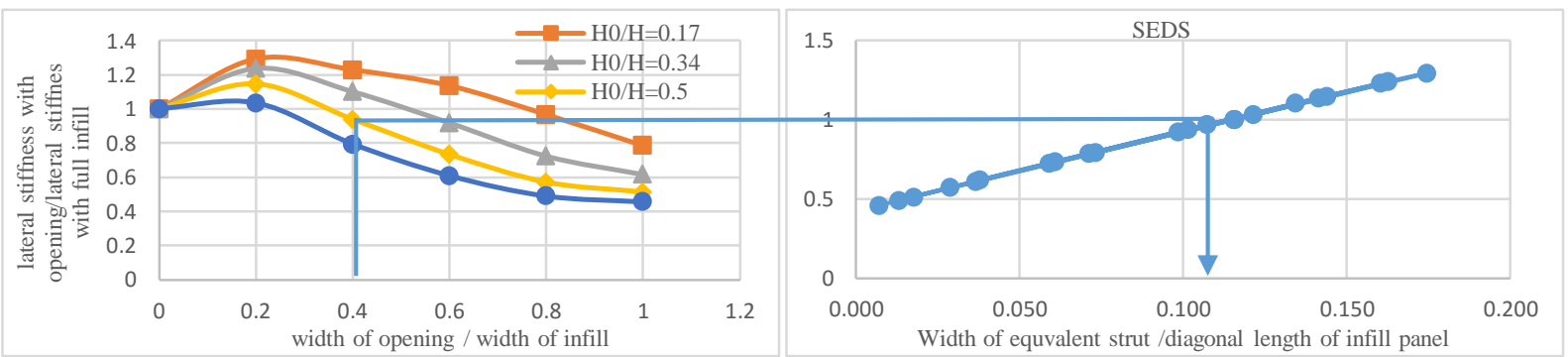

Fig 20 Single equivalent diagonal strut for lintel $150 \mathrm{~mm}$ stiffener

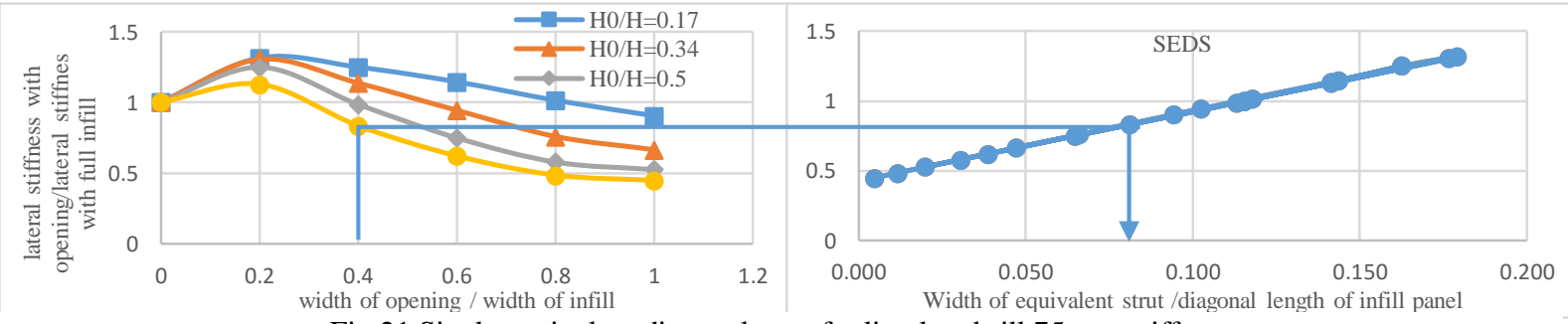

Fig 21 Single equivalent diagonal strut for lintel and sill $75 \mathrm{~mm}$ stiffener

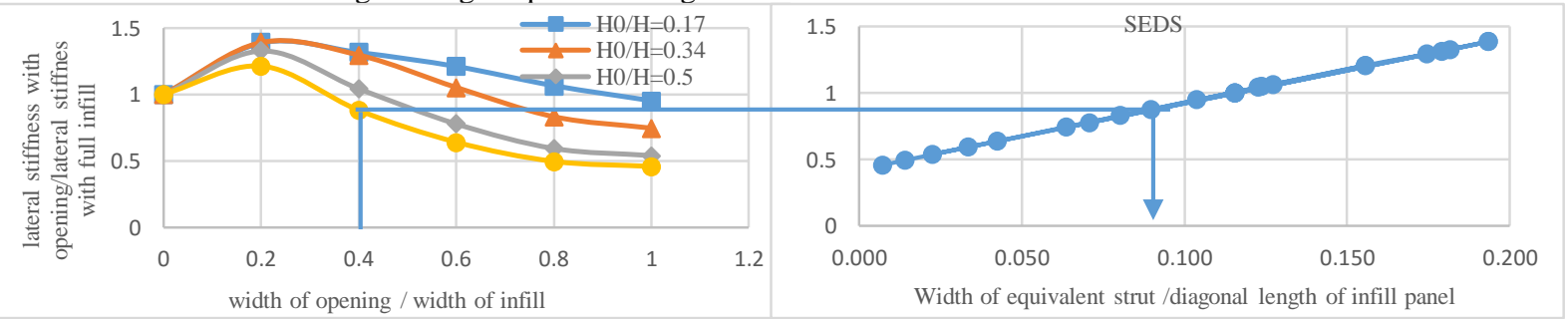

Fig 22 Single equivalent diagonal strut for lintel and sill $100 \mathrm{~mm}$ stiffener

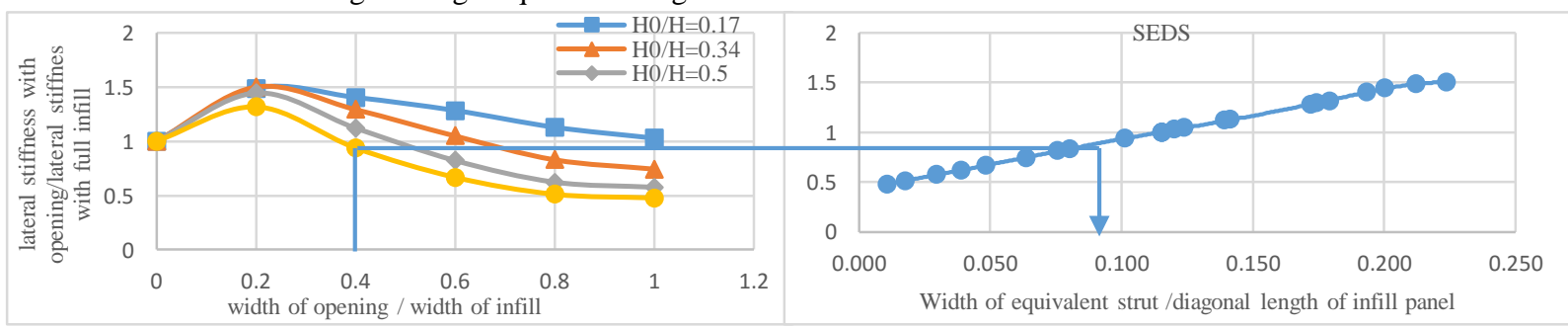

Fig 23 Single equivalent diagonal strut for lintel and sill $150 \mathrm{~mm}$ stiffener

Fig A. Effect of opening size varying aspect ratio on equivalent diagonal strut with various stiffener size

JScE Vol. 3, Dec 2015

Chandra Kiran Kawan 13 


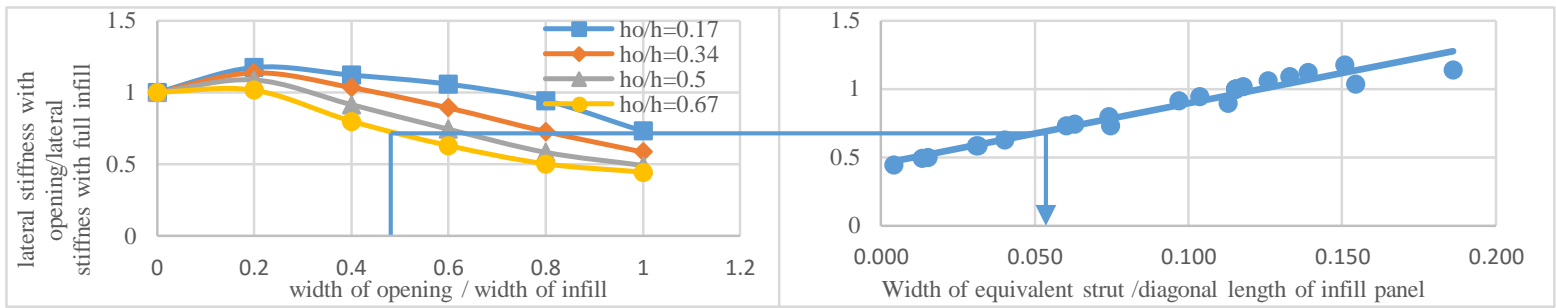

Fig 24 Single equivalent diagonal strut for $75 \mathrm{~mm}$ lintel stiffener with wooden frame

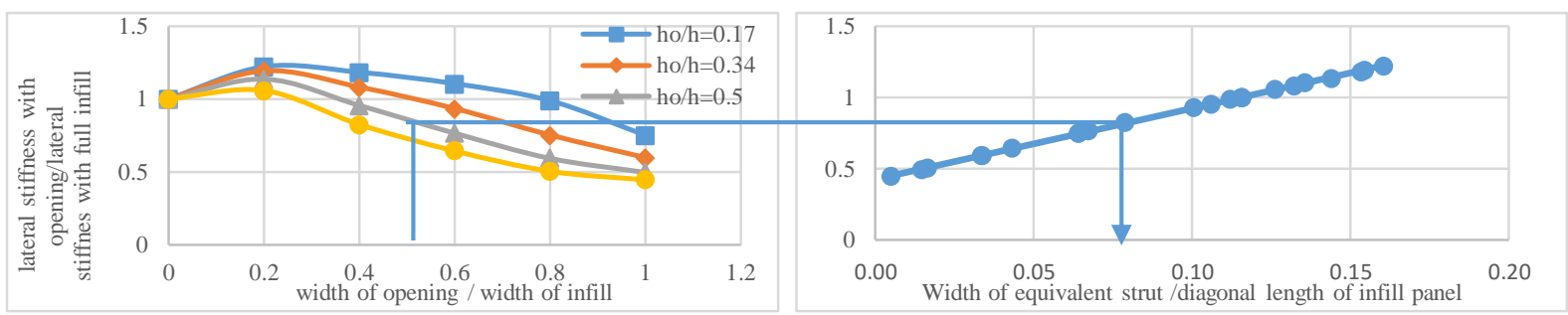

Fig 25 Single equivalent diagonal strut for $100 \mathrm{~mm}$ lintel stiffener with wooden frame

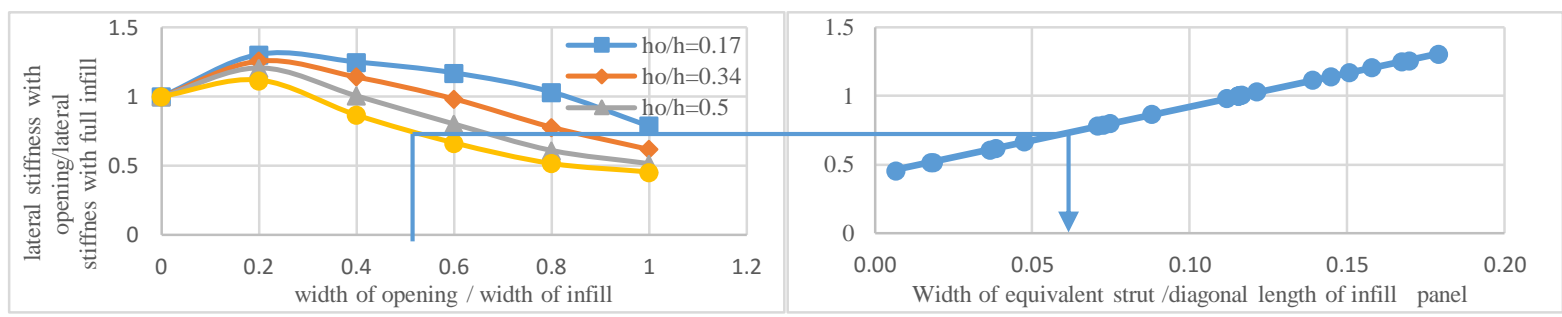

Fig 26 Single equivalent diagonal strut for $150 \mathrm{~mm}$ lintel stiffener with wooden frame

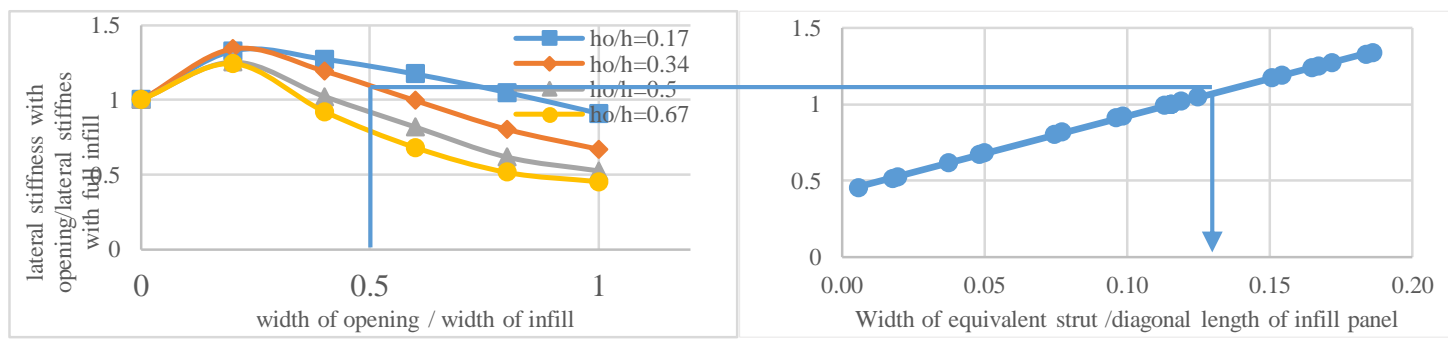

Fig 27 Single equivalent diagonal strut for $75 \mathrm{~mm}$ lintel and sill stiffener with wooden frame

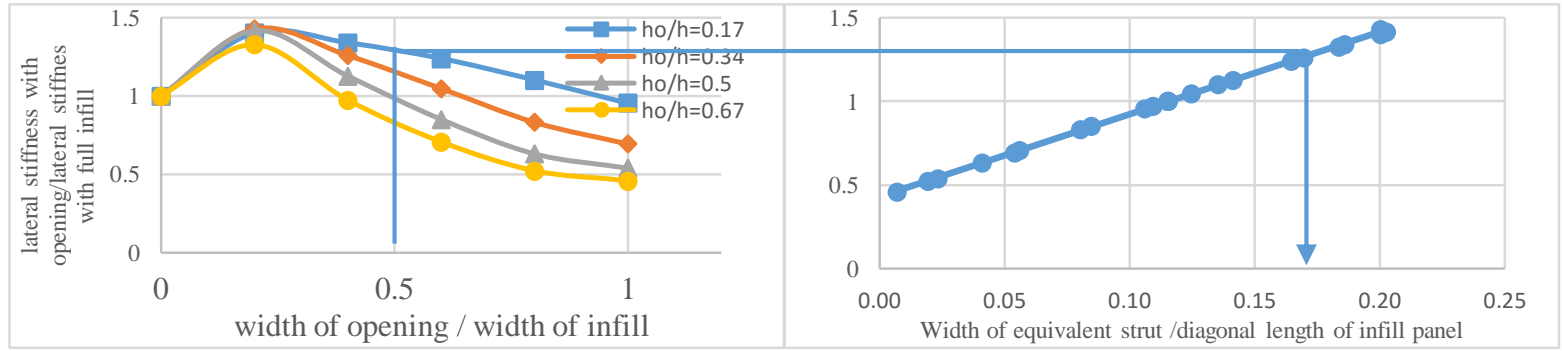

Fig 28 Single equivalent diagonal strut for $100 \mathrm{~mm}$ lintel and sill stiffener with wooden frame 


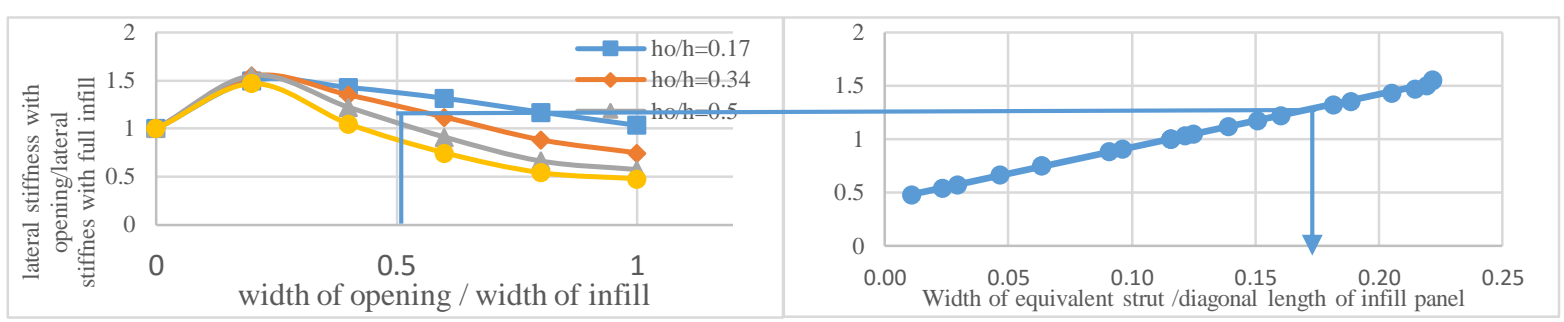

Fig 29 Single equivalent diagonal strut for $150 \mathrm{~mm}$ lintel and sill stiffener with wooden frame

Figure: B Strut width for infill with stiffeners of varying sizes and wooden frame around the opening

\section{Strut-width Reduction Factor}

The effect of opening on the lateral stiffness of the infilled frame can be represented by a diagonal strut of reduced width. This reduction in strutwidth can be represented by a factor $\left(\rho_{\mathrm{w}}\right)$, which is defined as ratio of reduced strut width ( $\mathrm{Wdo}$ ) to strut-width (Wds) corresponding to fully infilled frame.

Opening area ratio, $\alpha_{c o}$, is the ratio of area of opening, $A_{o p}$, with respect to area of infill panel $A_{\text {infill. }}$.

Strut width reduction factors for various opening area -ratios for are obtained (Fig 30 to Fig 46). It is observed that the area of opening is important for initial stiffness of infilled frame. Regression analysis of obtained data is performed and linear, second order polynomial and third order polynomial trend lines (Fig 30 to Fig 46). Also shown in the figures are the equations of the trend lines and the coefficient of correlation (R-value). The linear-fit follows the data reasonably well with $\mathrm{R}$ value of about 0.98 . The polynomials of higher order fit the data slightly better than linearfit with R-value about 0.99 . However, considering the simplicity the following linear, second order and third order polynomial regression equations adequately represent the data.

\section{Summary and Conclusion}

In practice, multistorey building are built with reinforced concrete frame and masonry infilled walls, which are usually designed assuming the infill walls to be nonstructural. The recent earthquake illustrate that infill walls has significant structural contribution in strength and stiffness so that infill wall should be taken into consideration in design process.
From this study it can be concluded that infill with opening size less than $5 \%$ can be treated as fully infilled frame and infill with opening size greater than $40 \%$ can be treated as bare frame. Use of stiffener (lintel and sill bands) compensate the decreased lateral stiffness due to opening. The effects of stiffeners decrease with increase in opening size. Beyond $40 \%$ opening size there is no effect of using stiffeners. Provision of different sizes of stiffeners as lintel band and sill band have shown significant increase in the stiffness of infilled frame up to $40 \%$ opening size. The gap element between the infill wall and stiffener reduces the stiffness of infilled frame drastically.

Also reduction in stiffness due to gap element is greater than stiffness increase by stiffeners. Opening aspect ratio also affects the stiffness of the infill frame system. Increase in stiffness due to different stiffeners is high for small aspect ratio compare to high aspect ratio of opening.

While embedding wooden window frame in the infilled frame, it does show negligible changes in lateral stiffness. But introducing the wooden frame in the infilled frame with lintel and sill band, there is significant change in lateral stiffness. However, by providing the gap element in the infilled frame with lintel and sill band with wooden frame, there is also negligible changes in lateral stiffness.

For single diagonal strut model of fully infilled frame it was proposed that the width of strut can be taken as one eighth of the diagonal length of the infill. This is very near to the previously done researches. The presence of central opening can be considered by reducing the effective width 
through a reduction factor, $\rho_{\mathrm{w}}$. Equivalent strut width increases with the application of stiffener. Similarly with increase in the thickness of stiffener also increases equivalent strut width. Introducing the gap element decreases the equivalent strut width. Also, the strut equivalent strut width increases for the wooden frame with lintel and sill band without gap element. For all possible combination, strut reduction factor equation with coefficient of correlation are proposed. Where opening are extended to full height or full width of infill frame, proposed reduction factor is not valid, i.e. proposed reduction factor is applicable for infilled frame with normal opening only.
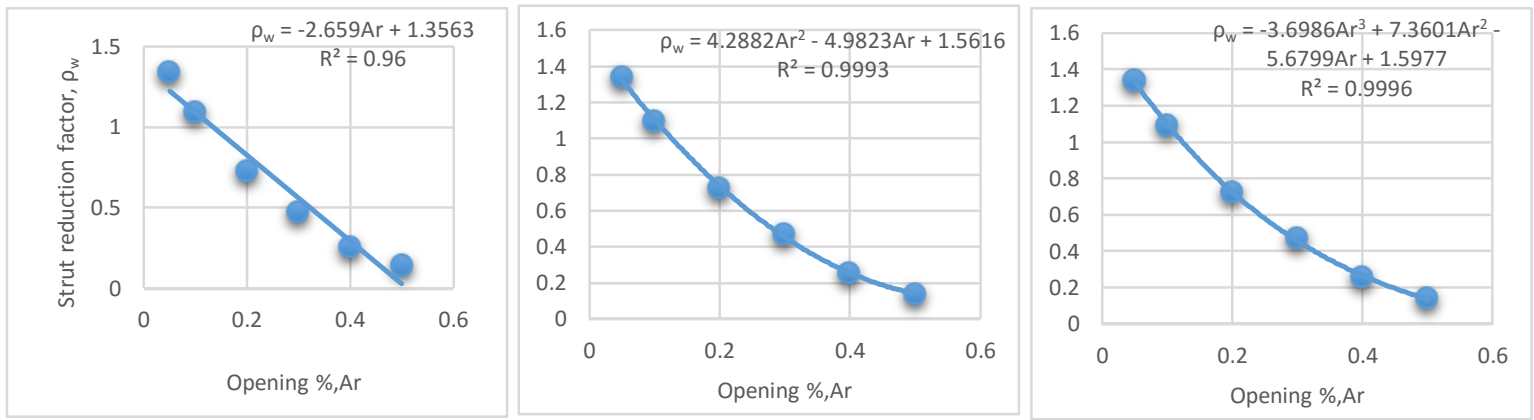

Fig 30 Lintel 75 mm Stiffener
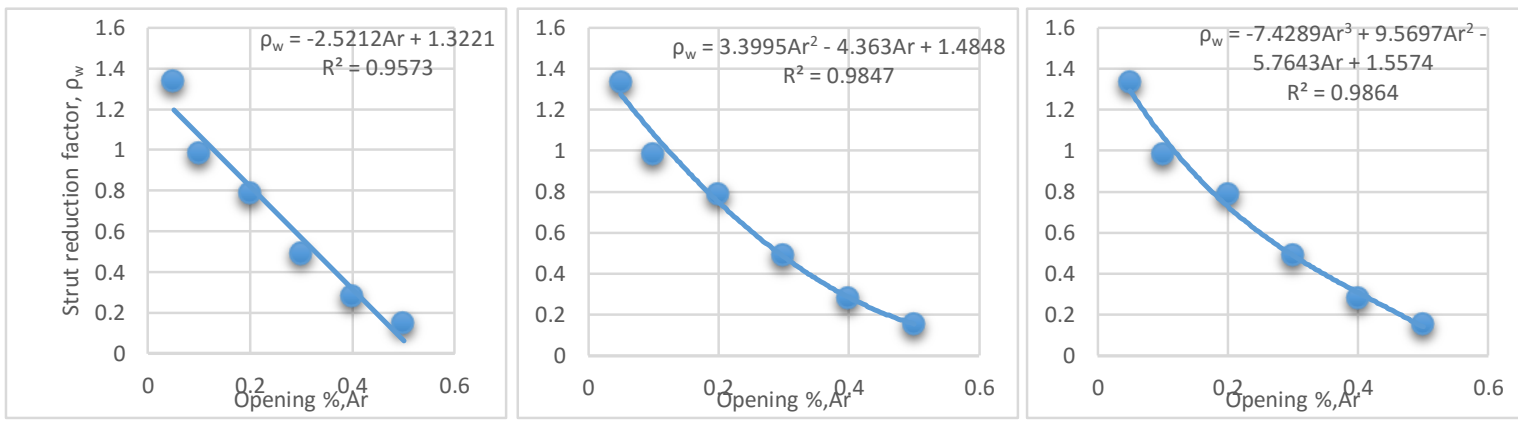

Fig 31 Lintel 100 mm Stiffener
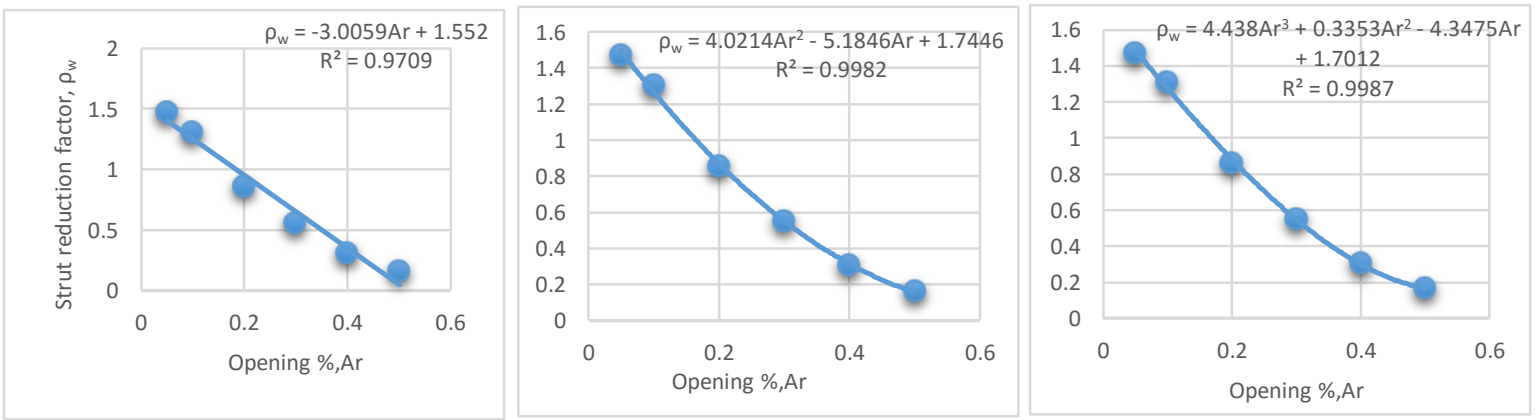

Fig 32 Lintel $150 \mathrm{~mm}$ stiffener 

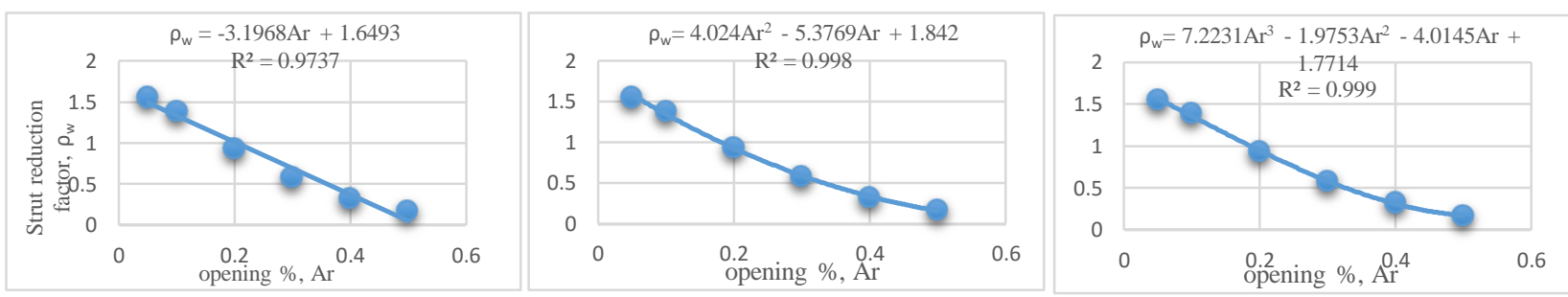

Fig 33 Lintel and sill $75 \mathrm{~mm}$ stiffener
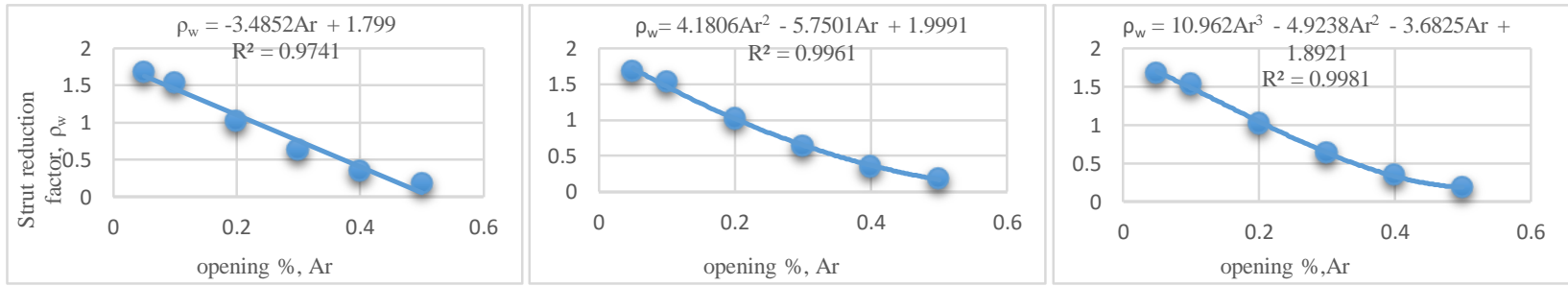

Fig 34 Lintel and sill $100 \mathrm{~mm}$ stiffener
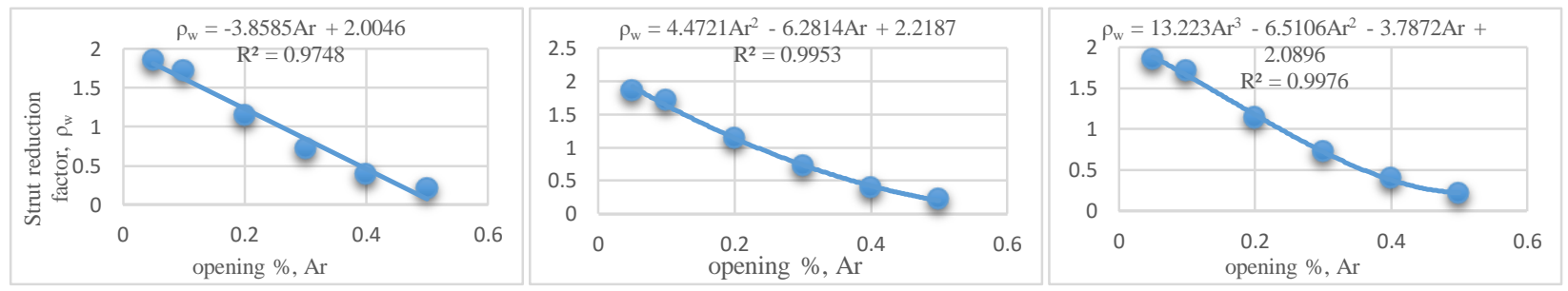

Fig 35 Lintel and sill $150 \mathrm{~mm}$ stiffener
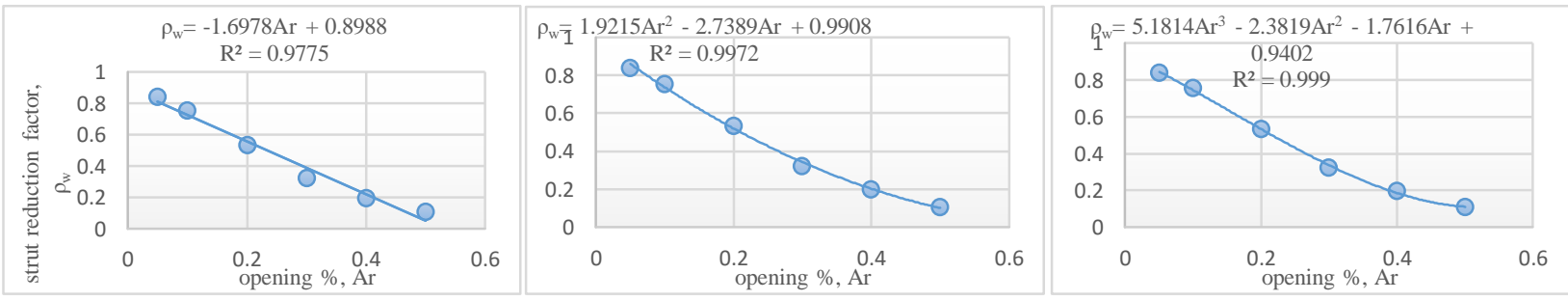

Fig 35 Lintel $75 \mathrm{~mm}$ stiffener with one side gap
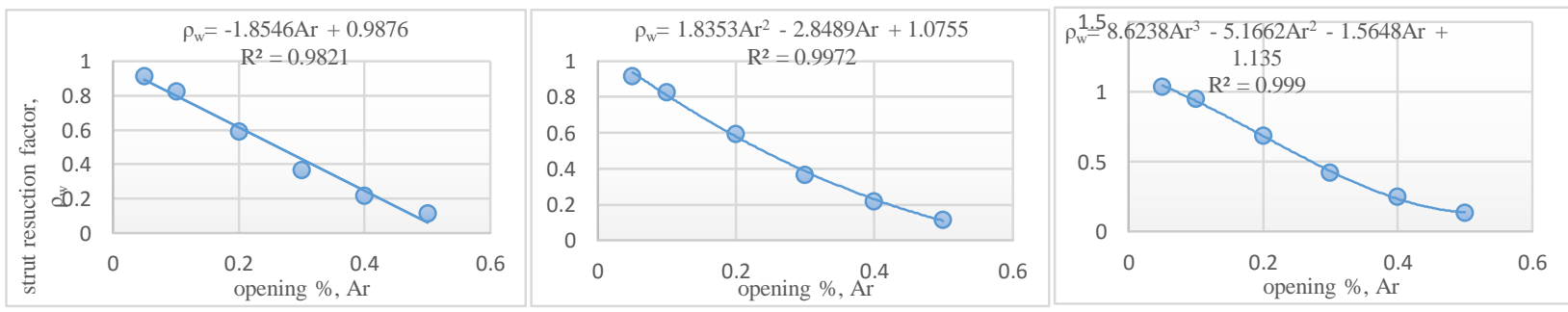

Fig36 Lintel $100 \mathrm{~mm}$ stiffener with one side gap
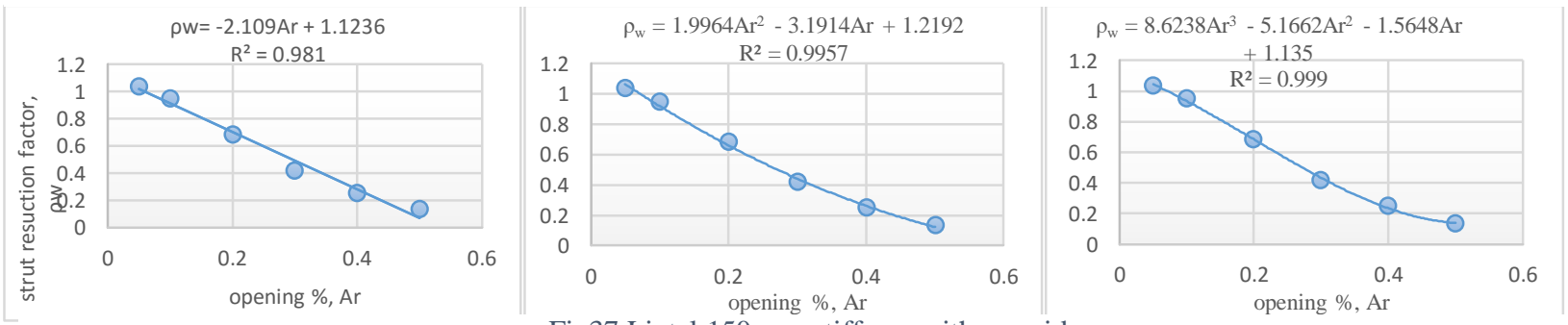

Fig37 Lintel $150 \mathrm{~mm}$ stiffener with one side gap 

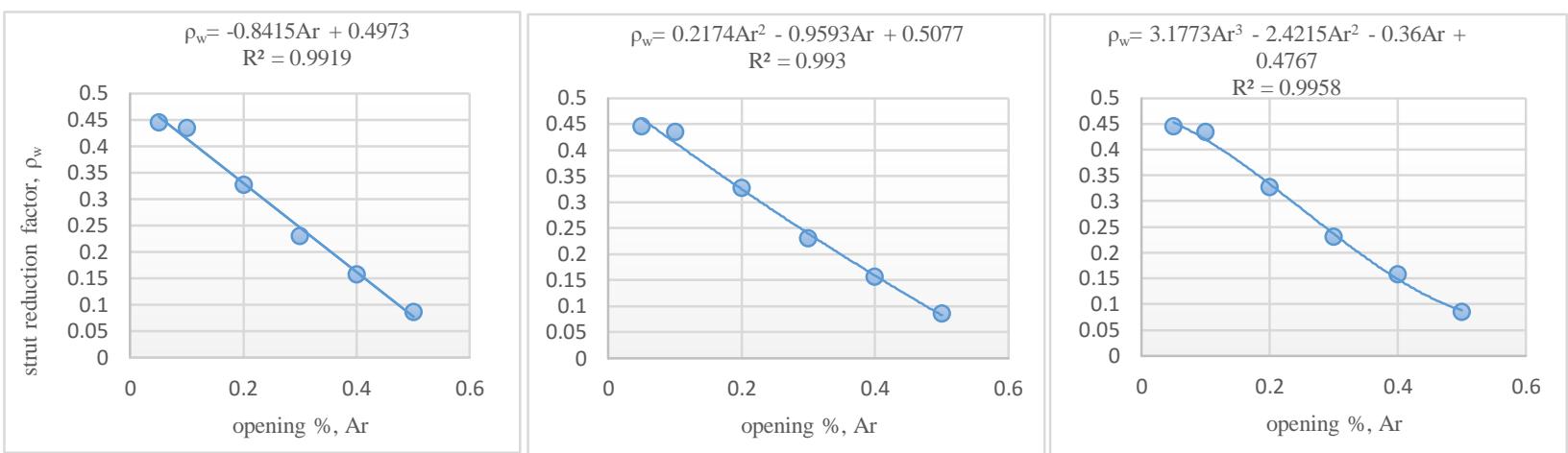

Fig 38 lintel and sill $75 \mathrm{~mm}$ stiffener with one side gap
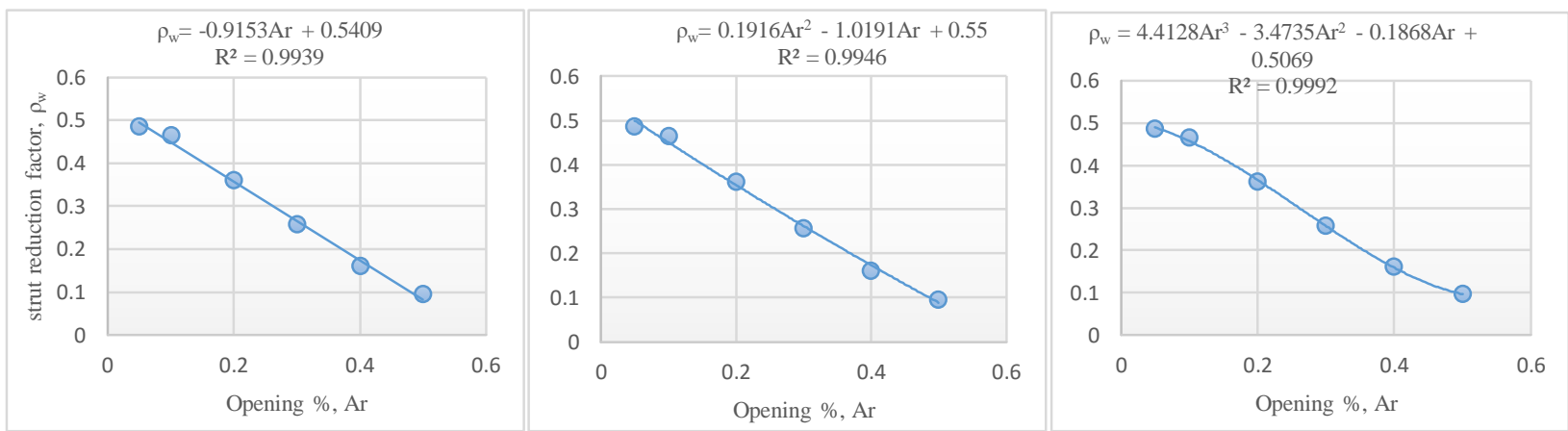

Fig 39 lintel and sill $100 \mathrm{~mm}$ stiffener with one side gap
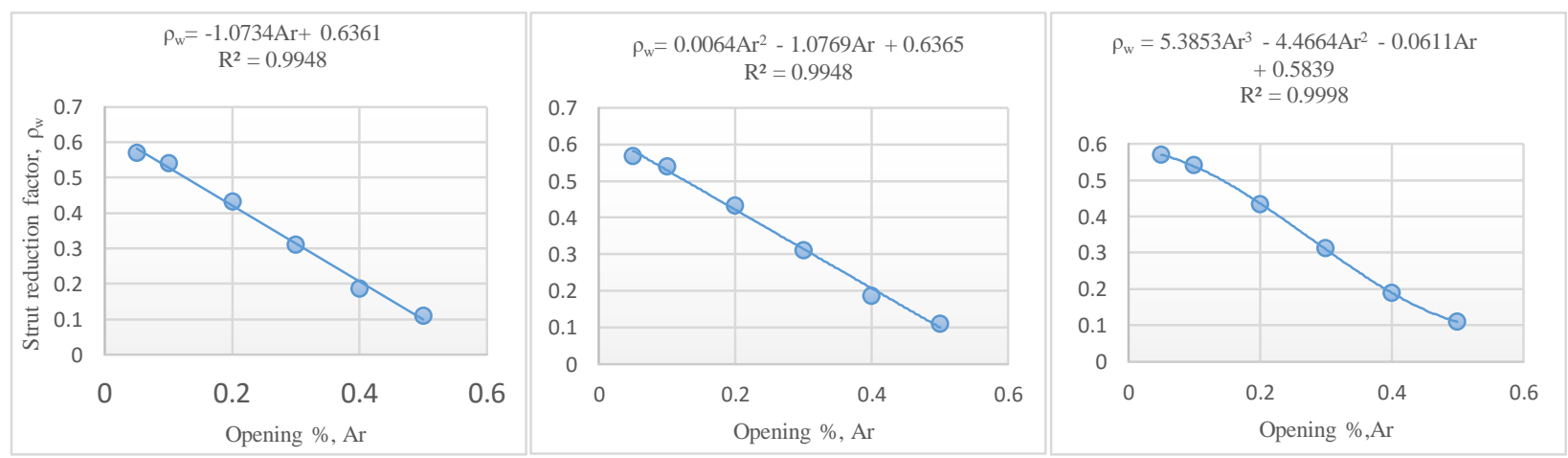

Fig 40 lintel and sill $150 \mathrm{~mm}$ stiffener with one side gap
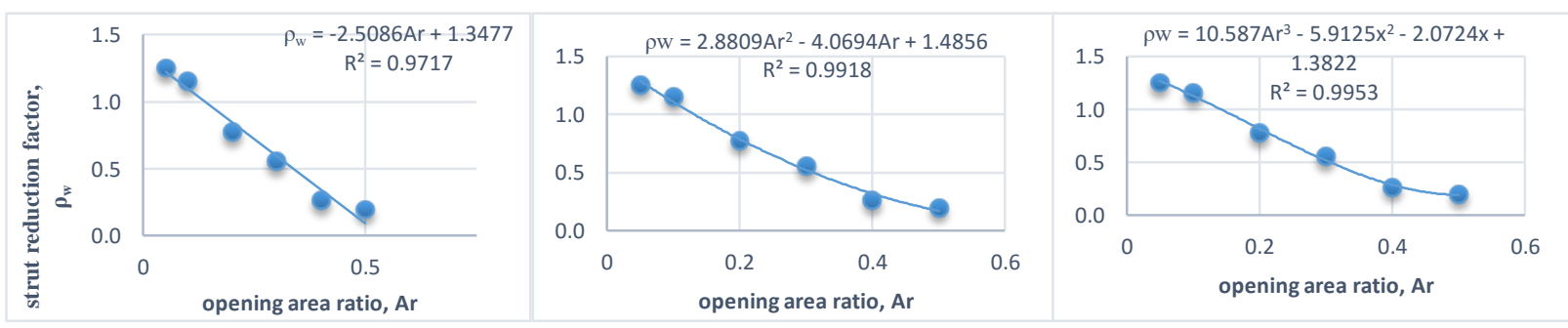

Fig 41 wooden frame with lintel $75 \mathrm{~mm}$ stiffener 

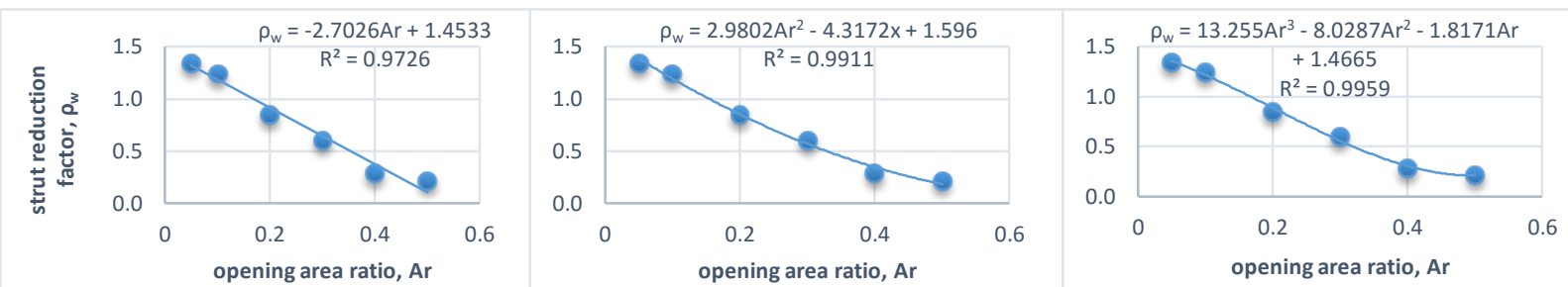

Fig 42 wooden frame with lintel $100 \mathrm{~mm}$ stiffener

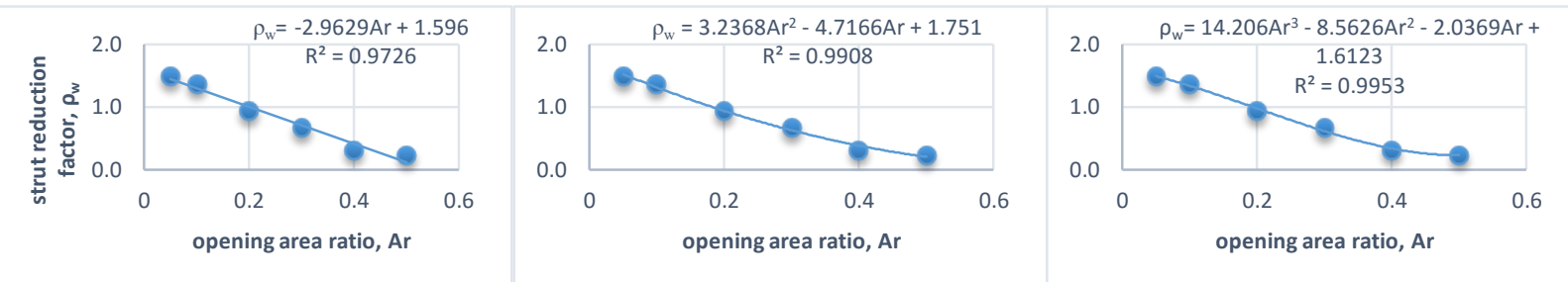

Fig 43 wooden frame with lintel $150 \mathrm{~mm}$ stiffener
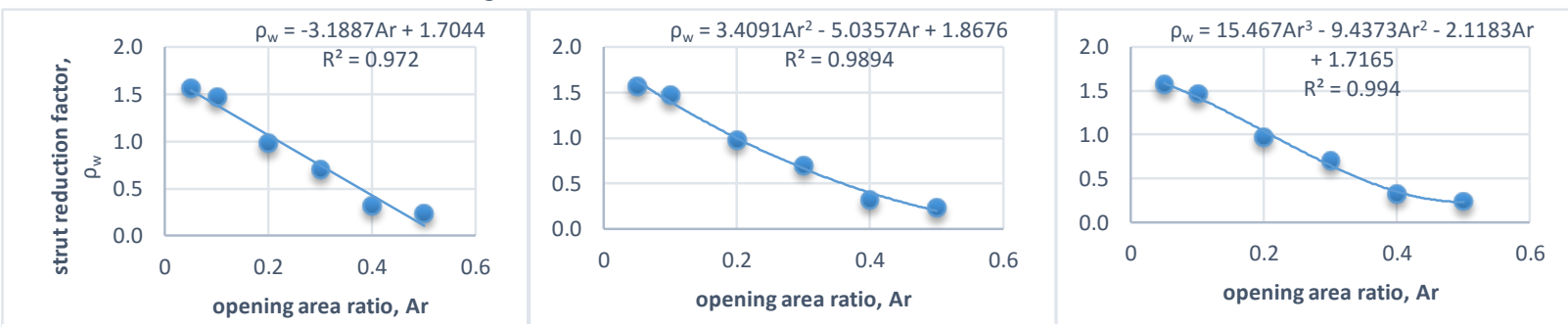

Fig 44 wooden frame with lintel and sill $75 \mathrm{~mm}$ stiffener
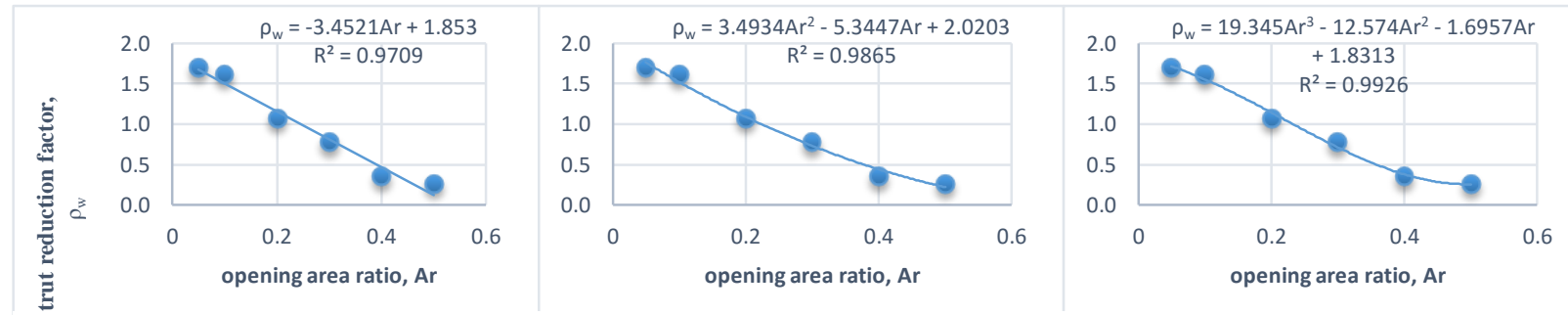

Fig 45 wooden frame with lintel and sill $100 \mathrm{~mm}$ stiffener
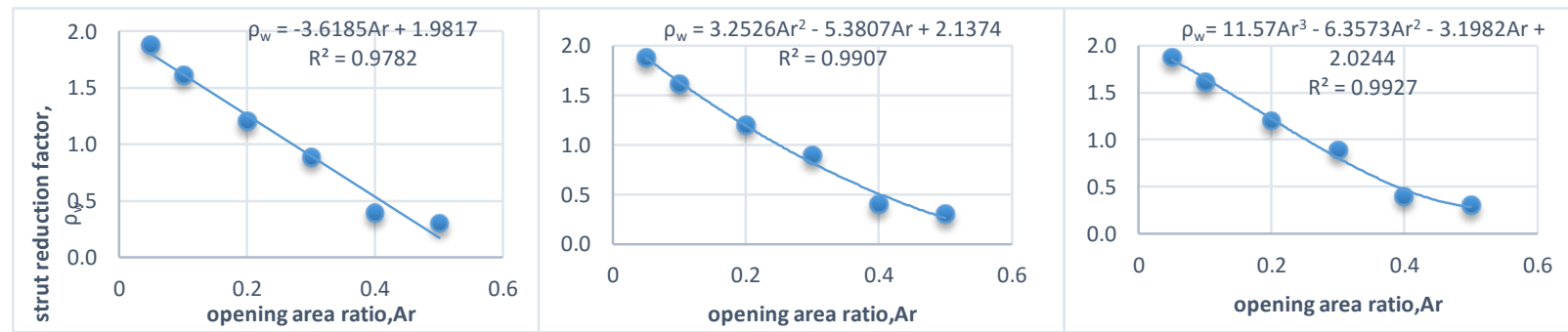

Fig 46 wooden frame with lintel and sill $150 \mathrm{~mm}$ stiffener

Figure C: Strut width reduction factor for various opening area ratio for different conditions

The present study is limited for single storey, single bay to infilled frames with central opening. Future work can be carried to study the effect of position of opening and stiffened openings for multi-story and multi bay infilled frames. Another aspect that can be studied in the future work is regarding short column effects with increase in the thickness of stiffeners.

\section{Acknowledgement:}

I would like to thanks undergraduate students Rabin Chakatu and Rajesh Suwal for their help for this research and also I would like to thank Sunil Duwal, Vice Principal, Khwopa College of Engineering for his help in formatting this paper. Finally, I would like to acknowledge Khwopa 
Engineering college and Khwopa College of Engineering for providing vital plateform to publish research articles.

\section{References}

[1] Al-chaar, G., 2002. Evaluating strength and stiffness of unreinforcement masonry infill structures. Construction engineering research laboratory, ERD/CERL TR-02-1, US Army corps of engineering.

[2] Buch, S.H.J. and Bhat, J. A., 2012. In-Plane Behaviour of Masonry Infilled Reinforced Concrete Frame with wooden Choh-kat Opengins. International Journal of Engineering and Advanced Technology, vol-2, Issue- 2 .

[3] Bureau of Indian Standards (IS:1893-2002, part 1), 2002. Indian Standard Criteria for Earthquake Resistant Design of Structure, General Provisions and Building, Fifth Revision, New Delhi.

[4] Decanini, L.D., Liberatore, L., and Mollaioli, F., 2012. The influence of opening on the seismic behavior of infilled framed structures, 15WCEE, lisoa.

[5] Dorji, J. and Thambirtnam, D.P., 2009. Modelling and analysis of infilled frame structure under seismic loads. The open construction and building technology journal, 2009, vol-3, pg 119-126.

[6] Durrani, A.J. and Luo Y.H, 1994. Seismic retrofit of flat slab buildings with masonry infills. NCEER workshop on seismic response in masonry infill.
[7] G., Mondal and Jain, S. K., 2008. Lateral stiffness of masonry infilled reinforcement concrete $(\mathrm{RC})$ frames with central opening. Earthquake Spectra, vol-24, No.3, pg701-723.

[8] Kasnale, A.S. and Jamkar, Sanjay, 2012. Analysis of lateral stiffness for infilled frame with opening. International Journal of Advanced technology in civil engineering, ISSN: 2231-5721, vol-1, Issue-3. Mainstone, R. J, 1971. On the Stiffness and strengths of infilled frames. Proceedings Institution of civil engineers, London, UK, supplement IV, paper 7360S, pg 57-90.

[9] Mohammad, H.J., Patel, V.R., 2014. Analysis of RC frame with and without masonry infill wall with different stiffness with outer central opening. IJRET, vol-3, Issue-6.

[10] Murty, C.V.R. \& Jain, S.K., 2000. Beneficial influence of masonry infills on seismic performance of RC buildings. 12th World Conference on Earthquake Engineering. New Zealand.

[11] Nepal National Building Code (NBC 105:1994), 1994. Seismic design of buildings in Nepal, Ministry of Physical Planning and works, Kathmandu, Nepal.

[12] P., Arjun, M.V., Renuka Devi, K.R. , Ashok, S., Manjunath, M.B., Somanath, 2014. Effect of stiffeners on the lateral stiffness of infill frames with openings. International journal of research in engineering and technology, vol-03 special issue: 06

[13] Pauley, T. \& Priestley, M.N.J., 1992. Seismic Design of reinforced concrete and masonry buildings, John Wiley \& Sons. 